体力科学 (1994) 43, 415 425

\title{
男女スポーツ競技者の身体密度推定式
}

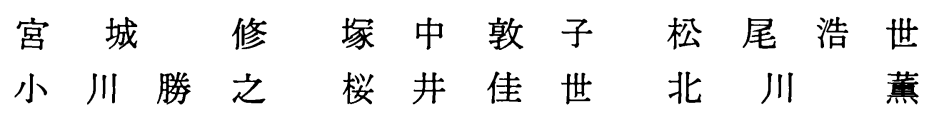

\section{EQUATIONS FOR PREDICTING BODY DENSITY IN MALE AND FEMALE ATHLETES}

\author{
Osamu Miyagi, Atsuko Tsukanaka, Hiroyo Matsuo, Katsuyuki Ogawa, \\ Kayo Sakurai and Kaoru Kitagawa
}

\begin{abstract}
This study was designed to determine prediction equations of body density (BD) for athletes using anthropometric variables and to examine validity of the prediction equations. The subjects were 211 male and 198 female athletes aged 18 to 22 years. The subjects were measured for standing height, body weight, skinfold thickness, girth as well as body composition. Body composition was estimated from densitometry using underwater weighing method and pulmonary residual volume measurement. Skinfold thickness was measured at 9 sites on the right side of the body with an Eiken-type skinfold caliper and 7 measures of girth were taken using a cloth tape. All measurements were done three times from April to October : pre-, mid- and post-competitive season, in order to find out a suitable site reflecting body composition change. Using multiple regression analysis, equations to estimate BD were obtained from standing height, body weight, skinfold thicknesses and girths. The effective prediction equations for $\mathrm{BD}$ were as follows :

For Males

$\mathrm{BD}=1.11104-0.00053$ (sum of chest, abdomen and quadriceps skinfold thicknesses in $\mathrm{mm}$ ) 0.00027 (waist girth in $\mathrm{cm}$ ).

$\mathrm{R}=0.851$, SEE $=0.0051$.

For Females

$\mathrm{BD}=1.11861-0.00054$ (sum of abdomen, triceps and subscapula skinfold thicknesses in $\mathrm{mm}$ ) 0.00054 (waist girth in $\mathrm{cm}$ ).

$\mathrm{R}=0.826$, $\mathrm{SEE}=0.0062$.

A cross-validation analysis of these prediction equations for $\mathrm{BD}$ correlated highly with hydrodensitometrically determined $\mathrm{BD}(\mathrm{r}=0.832$, $\mathrm{SEE}=0.0053$ for males and $\mathrm{r}=0.812$, $\mathrm{SEE}=$ 0.0062 for females). Thus the prediction equations developed in the present study will be applicable to athletes.
\end{abstract}

(Jpn. J. Phys. Fitness Sports Med. 1994, $43: 415 \sim 425$ )

key words : Body composition, Skinfold thickness, Athletes, Cross-validation

\section{I. 結}

スポーツ競技者は年間を通じて一定の強度や量 のトレーニングを継続して行らことは少なく，鍛 練期では年間において最もトレーニング強度や量
が高く，その一方，オフ期のトレーニングはその 約半分以下の強度や量で行われているのが一般的 である，そのため，年間の各時期において競技者 の体脂肪量と除脂肪体重 (Lean Body Weight, 以 下 LBW) にかなりの変化が生じていることは報 
告されている $4,5,7,15,21,24,31)$. 一方, LBW は筋肉 量を示すよい指標であるため, トレーニング効果 および競技者の運動能力を理解するらえで重要な 指標である．これらのことから，スポーツ競技者 の身体組成を高い精度で測定することは競技者に とって極めて有用である.しかし，実際の現場に おいてコーチなどの指導者は選手の体調をみるう えで，未だに体重を重視する傾向にあり，ただ単 に体重の増加や減少に関心を向けがちである. そ のために選手の減量に拈いては体脂肪量ばかりで なく，LBW までをも減少したり，増量において は体脂肪量が増加してしまらなど，スポーツ競技 者として好ましくない問題が生ずる結果となって いる ${ }^{11,13)}$.

これまでに，簡便に身体組成を測定する方法で 広く普及しているキャリパーにより皮脂厚を測定 して全身の身体組成を推定するといら試みは海 外, 特にアメリカでは思春期 ${ }^{18)}$, 青年期 $\left.{ }^{3,9}, 10,30\right)$ お。 よび中年期 ${ }^{16,25,26)}$ など集団を対象として数多く 報告されてきた。また，スポーツ競技者について は高校生男子レスラー選手 ${ }^{8)}$ 扑よび女子競技者 ${ }^{17}$, 22,28)を対象とした報告がなされてきた、にもかか わらず，我国のスポーツの現場においては1964年 に作成された一般青年を対象とした Nagamine and Suzuki の推定式 ${ }^{23)}$ が広く利用されているの が現状である. しかし，この推定式はスポーツを 特に行なっていない20代の一般青年を対象に作成 されたものである．そのために20代の一般青年以 外の者を対象とした場合，十分な推定精度を得る ことはできないことが指摘されている12,14).そこ で, 本研究の目的は皮脂厚や周径囲からなる形態 計測値から男女スポーツ競技者の身体密度推定式 を作成し，かつ作成した身体密度推定式の妥当性 を検討することである.

\section{II. 方法}

\section{A. 対}

被検者は大学体育会のクラブに所属し，その種 目の競技歴が 5 年以上のスポーツ競技者であっ た. 被検者数は身体密度推定式の作成に用いた標 本として男子が 160 名, 女子が 150 名であり,さ
らに作成した身体密度推定式の妥当性を検討する ための Cross-validation に用いた異なる標本と して男子が51名，女子が48名であった。対象とな った競技種目は，陸上競技 (短距離走, 跳羅, 長 距離走, 投擲) 男女, 水泳男女, バスヶットボー ル男女, ハンドボール男女, バレーボール男女, サッカー男子, ラグビー男子およびボート女子で あった。

\section{B. 測定項目}

測定は全身の身体組成が水中体重秤量法による 密度法, 皮脂厚はキャリパー, そして周径囲は布 製の巻尺を用いて測定した。 また，全ての皮脂厚 と周径囲の測定は男女各 1 名の検者によって行わ れた、なお，これらの測定は早朝空腹時の排便排 尿後に実施された，測定手順等の詳細は，以下の とおりである.

\section{1. 水中体重秤量法による密度法の測定}

被検者は水温が35 $37^{\circ} \mathrm{C}$ に調節された深さ $1.5 \mathrm{~m}$ の水槽に入り，水槽の底に設定した椅子型 体重計(AD-6204型：エー・アンド・デイ社製)に 腰を掛けて，最大呼出後の状態で水中体重を求め

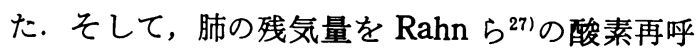
吸法により測定した後に身体密度を求め, Brožek ら 2)の式を用いて体脂肪率を算出し，体脂肪量と LBW を求めた.

\section{2. 皮脂厚の測定}

皮脂厚は栄研式キャリパー(明興社製)を用いて 測定したが，キャリパーの圧力が $10 \mathrm{~g} \cdot \mathrm{mm}^{-2}$ に なるよらに，測定の前に常に調節して用いた。測 定の際は, 被検者に楽な状態で起立姿勢をとらせ た. 測定部位は胸部, 側胸部, 臍部, 側腹部, 上 腕背部, 肩甲骨下角部, 大腿前部, 大腿後部拈よ び下腿後部の 9 ケ所であった。胸部は男子が乳頭 の上，女子が乳頭と鎖骨の中点を結ぶ線上でその 中点, 側胸部は中腋窝線で剣状突起の高さ, 臍部 は臍の右横 $1 \mathrm{~cm}$, 側腹部は中腋窝線で胙の高さ, 上腕背部は肩峰点と橈骨点とを結ぶ線の中点でそ の背側, 肩甲骨下角部は肩甲骨下角直下, 大腿前 部は腸棘点と㮏蓋骨とを結ぶ線上の中点でその前 側, 大腿後部は大腿前部での計測点の背側そして 下腿後部は脛骨点から腫点の間の遠位 $30 \%$ ぞその 
背側を $0.5 \mathrm{~mm}$ 単位で測定した。なお，全ての部 位について右体側部を測定した.

\section{3. 周径囲の測定}

周径囲は布製の巻尺を用いて測定した。測定項 目は胸囲, 臍位腹囲, 腹部最小囲, 臀囲, 上腕囲, 大腿囲扣よび下腿囲であった，胸囲は男子が乳頭 上，女子が乳頭の上位と肩甲骨下角直下を通る位 置での呼吸中間位, 臍位腹囲は臍位置での水平方 向の周径, 腹部最小囲は肋骨弓と腸骨稜との間で 最も細い部分, 层囲は层部の最大膨大部, 上腕囲 は肩峰点と橈骨点を結ぶ線の中点の周径, 大腿囲 は腸棘点と膝蓋骨とを結ぶ線上の中点の周径そし て下腿囲は脛骨点から腫点の間の遠位30\%の位置 の周径を $1 \mathrm{~mm}$ 単位で測定した.

\section{C. 測定時期}

身体密度推定式の作成に用いた標本については 1992年のシーズン中に上記の測定を 3 回実施し た.これは作成する身体密度推定式の測定部位の 選択にあたって，シーズン中の体脂肪量の変化に 対応して，どの測定部位の皮脂厚および周径囲が 変化するかを明らかにするためであった．1回目 の測定はシーズンに入る前の鍛練期の終了後 ( $3 \sim 4$ 月), 2 回目の測定は 7 月から 8 月中旬に かけて行われる西日本学生選手権大会の終了直 後, そして 3 回目の測定は 9 月から10月中旬にか けて行われる全日本大学選手権大会の終了直後に 行った. また, Cross-validation に用いた標本に ついては1993年の 4 月に測定した.

\section{D. 統計忛理}

データの統計処理は Pearson の相関係数, そ して差の検定は Wilcoxon の符号付順位和検定と 対応のある $\mathrm{t}$ 検定を用いて行った. 身体密度推定 式は水中体重秤量法による身体密度を従属変数と し, 皮脂厚および周径囲を独立変数とした重回帰 分析により求めた. そして, 推定精度は重相関係 数（以下，R) および推定の標準誤差 (Standard Error of Estimation, 以下 SEE) で示し，統計上 の有意水準は $5 \%$ とした. 以上の計算処理は全 て統計処理ソフトウェアパッヶーシ SPSS/PC (SPSS JAPAN, Inc.) を用いて行った。
III. 結果

\section{A. 身体組成と形態との関係}

身体密度推定式の作成に用いられた標本の身体 的特徵は Table 1, そして Cross-validation に用 いられた標本については Table 2 に示した。また， シーズン前期に怙ける皮脂厚および周 径囲と水 中体重秤量法による身体密度之の相関係数を Table 3 に示した．皮脂厚の測定部位の中で，水 中体重秤量法による身体密度との間に最も高い相 関関係を示した測定部位は，男女ともに臍部（男 子 $\mathrm{r}=-0.789$, 女子 $\mathrm{r}=-0.780)$ であった. そし て周径囲において高い相関関係を示した測定項目 は男女之も臍位腹囲(男子 $\mathrm{r}=-0.747$, 女子 $\mathrm{r}=-0.665)$ であり, 男女に共通して相関関係の 高かった部位は皮脂厚および周径用ともに腹部で あった。

\section{B. シーズン中の体重と身体組成の変化}

シーズン中に括ける体重と身体組成の变化を Table 4 に示した. 体重においては男女ともシー ズン前期と中期間，およびシーズン前期と後期間 で有意な減少がみられた，また，体脂肪率と体脂 肪量においては男女ともシーズン中の各測定時期 の間で有意な減少がみられた。そして，LBW に おいては男子でシーズン前期と後期間で有意な増 加がみられたが，女子ではシーズン中に有意な変 化はみられなかった。

\section{C. シーズン中の皮脂厚と周径讲の変化}

シーズン中に拉ける皮脂厚の変化を Table 5 に 示した. シーズン中を通じて皮脂厚の減少量が大 きかった測定部位は，男子が側腹部 $(-2.6 \mathrm{~mm})$, 臍部 $(-2.2 \mathrm{~mm})$ および大腿前部 $(-2.1 \mathrm{~mm})$ の 順であった：そして，女子は側腹部 $(-2.8 \mathrm{~mm})$, 臍部 $(-2.7 \mathrm{~mm})$ および胸部 $(-2.4 \mathrm{~mm})$ の順であ った. また, シーズン中の周径囲の変化を Table 6 に示した. その結果, 周径囲の減少量が大きかっ た測定項目は, 男子が臍位腹囲 $(-1.8 \mathrm{~mm})$, 腹 部最小囲 $(-1.5 \mathrm{~mm})$ 扎よび臂囲 $(-1.0 \mathrm{~mm})$ の 順であった.そして，女子は臍位腹囲 $(-2.0 \mathrm{~mm})$, 腹部最小囲 $(-1.3 \mathrm{~mm})$ および大腿囲 $(-1.0 \mathrm{~mm})$ の順であった。 


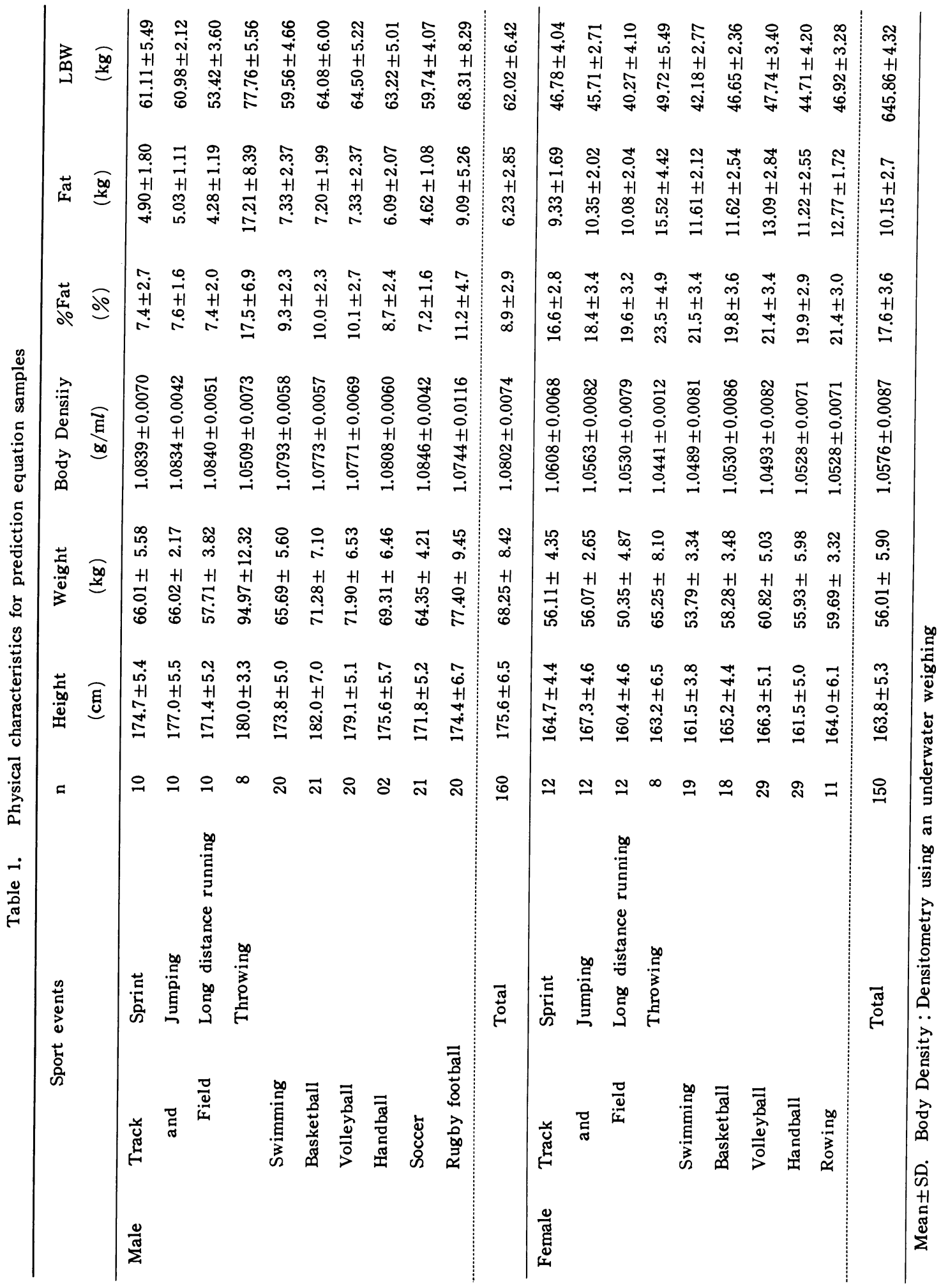


Table 2. Physical characteristics for cross-validation samples

\begin{tabular}{|c|c|c|c|c|c|c|c|c|}
\hline \multicolumn{2}{|c|}{ Sports events } & $\mathrm{n}$ & $\begin{array}{l}\text { Height } \\
(\mathrm{cm})\end{array}$ & $\begin{array}{c}\text { Weight } \\
\text { (kg) }\end{array}$ & $\begin{array}{l}\text { Body Density } \\
\qquad(\mathrm{g} / \mathrm{m} l)\end{array}$ & $\begin{array}{c}\% \text { Fat } \\
(\%)\end{array}$ & $\begin{array}{l}\text { Fat } \\
(\mathrm{kg})\end{array}$ & $\begin{array}{l}\text { LBW } \\
(\mathrm{kg})\end{array}$ \\
\hline \multirow[t]{3}{*}{ Male } & Soccer & 22 & $165.1 \pm 4.8$ & $66.25 \pm 3.92$ & $1.0789 \pm 0.0060$ & $9.4 \pm 2.3$ & $6.25 \pm 1.69$ & $60.00 \pm 3.41$ \\
\hline & Swimming & 29 & $165.1 \pm 3.9$ & $69.02 \pm 6.17$ & $1.0744 \pm 0.0072$ & $11.2 \pm 2.9$ & $7.83 \pm 2.56$ & $61.19 \pm 4.41$ \\
\hline & Total & 51 & $160.4 \pm 4.6$ & $67.86 \pm 5.47$ & $1.0763 \pm 0.0070$ & $10.4 \pm 2.8$ & $7.16 \pm 2.35$ & $60.69 \pm 4.03$ \\
\hline \multirow[t]{3}{*}{ Female } & Sprint & 21 & $163.8 \pm 5.9$ & $55.47 \pm 3.46$ & $1.0548 \pm 0.0067$ & $19.0 \pm 3.9$ & $10.95 \pm 2.50$ & $45.28 \pm 7.23$ \\
\hline & Handball & 27 & $162.3 \pm 4.0$ & $58.05 \pm 5.23$ & $1.0535 \pm 0.0083$ & $19.6 \pm 3.4$ & $11.44 \pm 2.63$ & $46.60 \pm 3.90$ \\
\hline & Total & 48 & $163.8 \pm 5.3$ & $58.51 \pm 4.17$ & $1.0537 \pm 0.0086$ & $19.5 \pm 3.6$ & $11.46 \pm 2.35$ & $47.05 \pm 3.61$ \\
\hline
\end{tabular}

Mean \pm SD. Body Density: Densitometry using an underwater weighing

Table 3. Correlation coefficients between skinfold thickness or girth and body density in pre-season

\begin{tabular}{llcc}
\hline Measurment site & $\begin{array}{c}\text { Male } \\
(\mathrm{n}=160)\end{array}$ & $\begin{array}{c}\text { Female } \\
(\mathrm{n}=150)\end{array}$ \\
\hline Skinfold thickness & Chest & -0.776 & -0.713 \\
& Side Chest & -0.731 & -0.668 \\
& Abdomen & -0.789 & -0.780 \\
& Side Abdomen & -0.783 & -0.741 \\
Triceps & -0.655 & -0.691 \\
& Subscapula & -0.687 & -0.690 \\
& Quadriceps & -0.729 & -0.673 \\
& Biceps Femoris & -0.705 & -0.590 \\
Medial Calf & -0.585 & -0.457 \\
& Chest & -0.618 & -0.566 \\
Waist & -0.747 & -0.665 \\
& Minimum Abdomen & -0.708 & -0.566 \\
& Hip & -0.678 & -0.457 \\
Arm & -0.423 & -0.562 \\
& Thigh & -0.676 & -0.447 \\
& Calf & -0.494 & -0.603
\end{tabular}

All correlation coefficients are statistically significant at $\mathrm{P}<0.01$.

Table 4. Changes of weight and body composition through the competitive season

\begin{tabular}{ccccccc}
\hline & Season & $\begin{array}{c}\text { Weight } \\
(\mathrm{kg})\end{array}$ & $\begin{array}{c}\text { Body Density } \\
(\mathrm{g} / \mathrm{ml})\end{array}$ & $\begin{array}{c}\% \text { Fat } \\
(\%)\end{array}$ & $\begin{array}{c}\text { Fat } \\
(\mathrm{kg})\end{array}$ & $\begin{array}{c}\text { LBW } \\
(\mathrm{kg})\end{array}$ \\
\hline Male & Pre & $69.32 \pm 8.58$ & $1.0745 \pm 0.0087$ & $11.1 \pm 3.5$ & $7.91 \pm 3.54$ & $61.42 \pm 6.03$ \\
$(\mathrm{n}=160)$ & Mid & $68.70 \pm 8.37^{*}$ & $1.0776 \pm 0.0079^{*}$ & $9.9 \pm 3.1^{*}$ & $6.97 \pm 3.06^{*}$ & $61.73 \pm 6.22$ \\
& Post & $68.25 \pm 8.37^{*}$ & $1.0802 \pm 0.0074^{* \dagger}$ & $8.9 \pm 2.9^{* \dagger}$ & $6.23 \pm 2.85^{* \dagger}$ & $62.02 \pm 6.42^{*}$ \\
Female & Pre & $57.24 \pm 5.84$ & $1.0518 \pm 0.0087$ & $20.3 \pm 3.6$ & $11.71 \pm 2.84$ & $45.53 \pm 4.27$ \\
$(\mathrm{n}=150)$ & Mid & $56.37 \pm 5.80^{*}$ & $1.0553 \pm 0.0085^{*}$ & $18.9 \pm 3.5^{*}$ & $10.73 \pm 2.74^{*}$ & $45.64 \pm 4.23$ \\
& Post & $56.01 \pm 5.92^{*}$ & $1.0576 \pm 0.0087^{* \dagger}$ & $17.9 \pm 3.6^{* \dagger}$ & $10.15 \pm 2.76^{* \dagger}$ & $45.86 \pm 4.32$
\end{tabular}

Mean \pm SD. $\quad *: p<0.05:$ Pre vs Mid, Pre vs Post

$t: p<0.05:$ Mid vs Post 


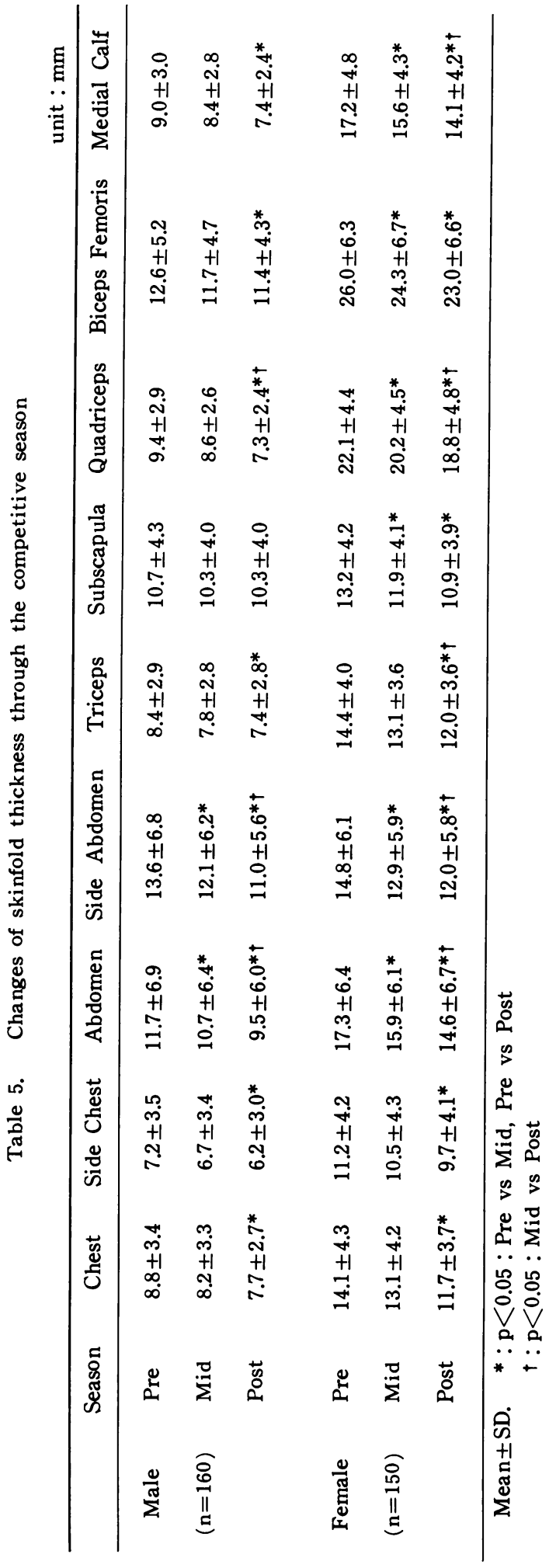

\section{D. スポーツ競技者の身体密度推定式}

我国のスポーツの現場においても広く利用され ている Nagamine and Suzuki の推定式 ${ }^{23)}$ ， 本 研究のスポーツ競技者の測定値を代入して得られ た推定身体密度と水中体重秤量法による身体密度 との関係を Fig. 1 に示した. その結果, 推定身体 密度と水中体重秤量法による身体密度との間に有 意な相関関係が認められたが，推定身体密度の平 均値は水中体重秤量法による身体密度の平均値に 比較して, 男女とも有意に過小評価され, 本研究 においても Nagamine and Suzuki の推定式はス ポーツ競技者の身体組成の推定に不十分であるこ とが分った．そこでスポーツ競技者の身体組成を より適切に推定できる身体密度推定式の作成を行 らこととした．推定式の作成にあたって考慮した のは水中体重秤量法による身体密度との相関関係 が高く, かつシーズン中の体脂肪量の変化に対応 して変化する皮脂厚および周径囲の部位を測定部 位とすることであった. その結果, 各部位の組合せ により得られた身体密度推定式の中から優れた推 定精度の推定式を Table 7 に示した. 最も推定精 度が優れている推定式の測定部位は, 男子が胸部, 胙部および大腿前部の皮脂厚和と臍位腹囲の周径 囲を独立变数に用いた式 $(\mathrm{R}=0.851, \mathrm{SEE}=0.0051)$ であった。 また，女子の測定部位は臍部，上腕 背部㧍よび肩甲骨下角部の皮脂厚和と胙位腹囲 の周径囲を独立変数に用いた式 $(R=0.826$, $\mathrm{SEE}=0.0062)$ であった。

\section{E. 本研究で作成した身体密度推定式の Cross-validity}

本研究で作成した身体密度推定式の妥当性を検 討するため, Cross-validation に用いられた標本 の測定值を代入して求めた推定身体密度と水中体 重秤量法による身体密度との関係を Fig. 2 に示 した．男女とも作成した身体密度推定式から求め られた推定身体密度と水中体重秤量法による身体 密度との間に，いずれる有意に高い相関関係が認 められ，かつそれぞれの方法から得られた身体密 度の平均値の間に有意な差は認められなかった。 そして, 推定身体密度と水中体重秤量法による身 体密度との間に得られた推定精度は身体密度推 
Table 6. Changes of girth through the competitive season

\begin{tabular}{ccccccccc}
\hline & Season & Chest & Waist & Minimum Abdomen & Hip & Arm & Thigh & Calf \\
\hline Male & Pre & $93.7 \pm 5.2$ & $76.5 \pm 5.7$ & $75.1 \pm 5.6$ & $92.4 \pm 4.5$ & $29.5 \pm 2.9$ & $56.1 \pm 3.7$ & $37.9 \pm 1.9$ \\
$(\mathrm{n}=160)$ & Mid & $93.8 \pm 5.8$ & $75.7 \pm 5.4$ & $74.1 \pm 4.9^{*}$ & $92.2 \pm 4.5$ & $29.7 \pm 2.5$ & $55.7 \pm 3.6$ & $38.1 \pm 1.8$ \\
& Post & $94.2 \pm 5.6$ & $74.7 \pm 5.4^{* \dagger}$ & $73.6 \pm 4.8^{*}$ & $91.4 \pm 4.4$ & $29.7 \pm 2.6$ & $55.6 \pm 4.2$ & $37.7 \pm 2.4$ \\
Female & Pre & $86.3 \pm 4.6$ & $74.5 \pm 5.7$ & $67.3 \pm 4.0$ & $91.2 \pm 3.6$ & $28.0 \pm 1.9$ & $56.0 \pm 3.1$ & $35.5 \pm 1.7$ \\
$(\mathrm{n}=150)$ & Mid & $87.0 \pm 4.5$ & $73.5 \pm 5.1$ & $66.5 \pm 3.8$ & $91.4 \pm 3.9$ & $27.8 \pm 2.0$ & $55.1 \pm 3.3$ & $35.6 \pm 1.6$ \\
& Post & $86.4 \pm 4.4$ & $72.5 \pm 5.4^{* \dagger}$ & $66.0 \pm 4.0^{*}$ & $90.8 \pm 3.7$ & $27.7 \pm 1.9$ & $55.0 \pm 3.2$ & $35.7 \pm 1.5$ \\
\hline
\end{tabular}

Mean \pm SD. $\quad *: \mathrm{p}<0.05:$ Pre vs Mid, Pre vs Post
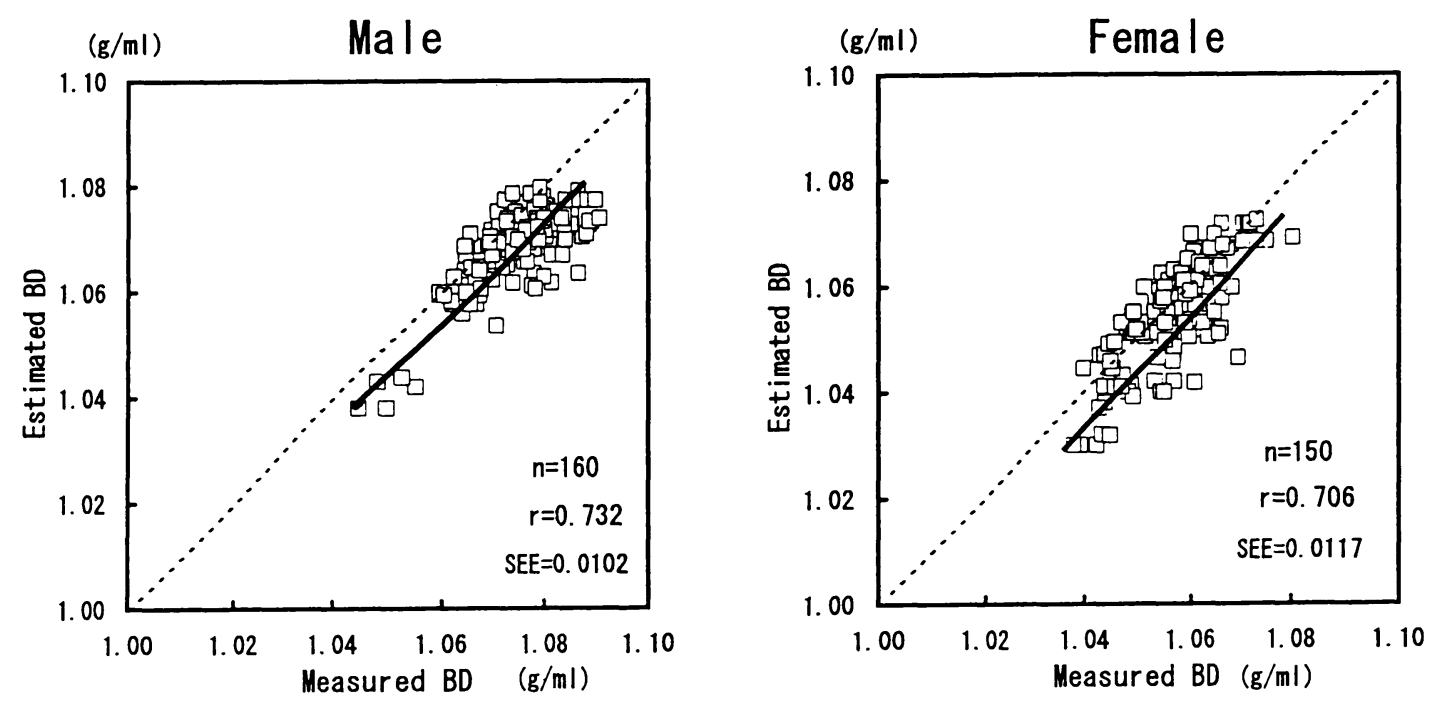

Fig. 1. Relationships between body density predicted from the equations of Nagamine and Suzuki and measured body density.

Table 7. Equations predicting body density of athletes

\begin{tabular}{|c|c|c|c|}
\hline & Prediction equatios $(\mathrm{g} / \mathrm{m} l)$ & $\mathrm{R}$ & $\operatorname{SEE}(\mathrm{g} / \mathrm{m} l)$ \\
\hline \multirow[t]{4}{*}{ Male } & $(\mathrm{n}=160)$ & & \\
\hline & (1) $\mathrm{BD}=1.11104-0.00053($ Chest + Abdomen + Quadriceps $)-0.00027$ (Waist $)$ & 0.851 & 0.0051 \\
\hline & (2) $\mathrm{BD}=1.11215-0.00043($ Chest + Abdomen + Subscapula $)-0.00032$ (Waist) & 0.842 & 0.0054 \\
\hline & (3) $\mathrm{BD}=1.12224-0.00055$ (Abdomen + Triceps +Quadriceps $)-0.00041$ (Waist) & 0.831 & 0.0056 \\
\hline \multicolumn{4}{|c|}{ Female $(n=150)$} \\
\hline & (1) $\mathrm{BD}=1.11861-0.00054($ Abdomen + Triceps + Subscapula $)-0.00054$ (Waist $)$ & 0.826 & 0.0062 \\
\hline & (2) $\mathrm{BD}=1.11441-0.00063$ (Abdomen+Triceps +Quadriceps $)-0.00037$ (Waist) & 0.815 & 0.0065 \\
\hline & (3) $\mathrm{BD}=1.11397-0.00066$ (Abdomen + Subscapula +Quadriceps) -0.00036 (Waist) & 0.809 & 0.0068 \\
\hline
\end{tabular}



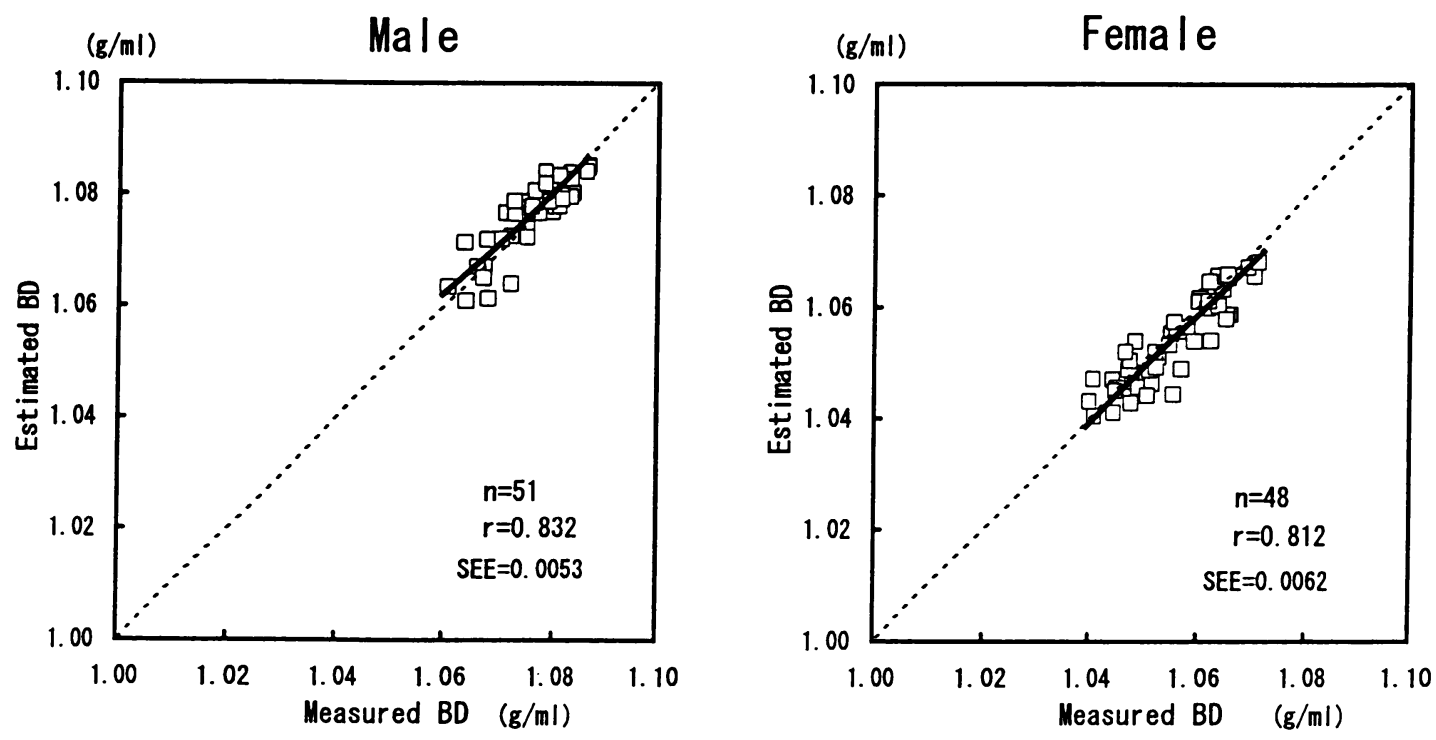

Fig. 2. Cross-validity of the prediction equations in this study.

定式作成時とほほ同様な結果（男子 $\mathrm{r}=0.832$, $\mathrm{SEE}=0.0053$, 女子 $\mathrm{r}=0.812, \mathrm{SEE}=0.0062)$ が得 られた.

\section{IV. 考察}

皮脂厚からの身体密度推定式を1951年に Brožek and Keys ${ }^{1)}$ が考案して以来, 現在に至る

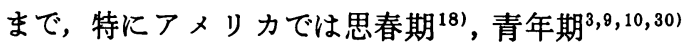
および中年期 ${ }^{16,25,26)}$ といった様々な年齢層やスポ 一ツ競技者 ${ }^{8,17,22,28,29)}$ についての推定式が数多く 報告されてきている，それに対して我国では 1964年に報告された Nagamine and Suzuki の 推 定式 ${ }^{231}$ が，その適用限界を無視され，唯一といっ てょいはど広汎な年齢層に用いられているばかり でなく，スポーツ競技者に対しても広く用いられ ている.そこで, Nagamine and Suzuki の推定 式がスポーツ競技者の身体組成を十分に推定する ことが可能であるのかを検討するため, Nagamine and Suzuki の推定式に, 本研究のスポー ツ競技者の測定値を代入して水中体重科量法によ る身体密度と比較してみた，その結果，推定身体 密度の平均値は水中体重秤量法による身体密度の 平均值に比較して男女とも有意に過小評価され，
Nagamine and Suzuki の推定式はスポーツ競技 者の身体組成を高い精度で推定することには適し ていないと考えられた。 そもそも Nagamine and Suzuki の 推定式はスポーツを特に行なっていな い一般青年を対象に作成されている，スポーツ競 技者は一般青年に比較して体脂肪率が小さいこ と $^{11,13)}$ ，そして皮脂厚は加龄や身体鍛練度の影響 を受けること ${ }^{14)}$ から, Nagamine and Suzuki の 推定式でのスポーツ競技者の推定は精度を低下さ せることになったと考えられる。

このような競技者の身体的特徵から，本研究で はスポーツ競技者の身体組成を高い精度で推定す るための身体密度推定式の作成条件として，水中 体重秤量法による身体密度と相関関係が高い部 位, かつシーズン中の体脂肪量の変化に対応して 変化する皮脂厚および周径用の部位を測定部位と した．本研究の結果より，作成条件を満たすには 主に腹部を中心とした部位を選択することが適切 であると考えられた。このような点に関して，福 永と金久 ${ }^{6)}$ の相撲選手と一般人肥満者を対象とし た超音波皮下脂肪厚計による皮下脂肪厚を測定し た報告がある、それによると，体幹に近位な部位 ほど皮下脂肪厚の沈着が著しく体脂肪量の増大に 
伴う皮下脂肪厚の沈着は腹部を中心として生じる とのことである．したがって，腹部は高い推定精 度を求めるらえでは欠くことのできない部位と考 えられる、また，作成した身体密度推定式はでき るたけ推定精度を高めるために, Nagamine and Suzuki の推定式で用いられているよらな単一変 量による回帰方程式を用いず，複数の独立変量に よる重回㷌方程式により求めた，その理由は, 直 線回帰方程式においても重回帰方程式においても 相関係数の大きさに違いがほとんどみられなかっ たものの, SEE に大きな違いがみられたためであ る.そして，各部位の組み合わせにより作成した 身体密度推定式の中から Rが高く, SEEが小さく, かつ身体組成の変化を反映する測定部位を含む推 定式を選択することとした。 その結果, Table 7 に示した式が適切と考えられたが，なかでも男子， 女子の各(1)式が最適の式と考えた.

なお，本研究はさまざまな競技種目の競技者を 対象として行われたが，全競技者をまとめて身体 密度推定式を作成した。 その点について, Malina ら ${ }^{19)}$ の報告を参考にした。すなわち Malina らは オリンピック選手の皮下脂肪の分布状態につい て，専門とする競技種目やトレーニング内容が皮 下脂肪の厚みそのものと関連付けられるが，身体 における皮下脂肪の分布状態には影響をもたない と報告している。したがって，本研究は男女各々， 全競技者の湘定值をまとめて統計処理を行なっ た.

一方, 本研究では作成した身体密度推定式の妥 当性を確認するために，推定式の決定に用いた標 本とは異なる標本を用いて検討したところ，男女 とも Table 7 に示した推定式とほぼ同様な推定精 度が得られた (Fig. 2). このことから，スポーツ 競技者の身体組成を推定する場合，これまでに広 く利用されてきた Nagamine and Suzuki の推定 式に比較するとかなり高い精度で身体組成を推定 できるものと考えられる.

なお，作成した身体密度推定式の推定精度は， 女子が男子に比較して低い結果であった。これは 身体密度推定式を男女別にみた研究に共通してみ られる傾向である ${ }^{23,25,26)}$. この要因として, 丸山
たち201は日本人青年男女を対象に超音波法による 皮下脂肪の分布の性差について検討しており，女 子は男子に比較して, 皮下脂肪分布の部位による 差が大きいことを報告している，そのため，女子 の推定精度は男子に比較して低いのではないかと 考党ている。

\section{V. 要 約と結 論}

本研究は，スポーツ競技者を対象として身体密 度推定式を作成し，かつ作成した身体密度推定式 の妥当性について検討した。 その結果, 身体密度 推定式の作成条件として水中体重秤量法による身 体密度と相関関係が高く, かつシーズン中の体脂 肪量の変化に対応して変化する皮脂厚および周径 囲の部位を測定部位とした。その結果，

男子には

身体密度 $=1.11104-0.00053 \mathrm{X}_{1}-0.00027 \mathrm{X}_{3}$

$(\mathrm{R}=0.851, \mathrm{SEE}=0.0051)$

女子には

身体密度 $=1.11861-0.00054 \mathrm{X}_{2}-0.00054 \mathrm{X}_{3}$

$(\mathrm{R}=0.826, \mathrm{SEE}=0.0062)$

$\mathrm{X}_{1}$ : 胸部, 臍部, 大腿前部の皮脂厚和

$\mathrm{X}_{2}$ : 臍部, 上腕背部, 肩甲骨下角部の皮脂 厚和

$\mathrm{X}_{3}$ ：臍位腹囲 がスポーツ競技者の身体密度推定式としてもっと も適切と考えられた。 また，この身体密度推定式 の妥当性については Cross-validation に用いら れた標本により検討したところ，ょり精度の高い 推定ができたことを確認した．以上のことから， スポーツ競技者を対象として，形態計測値から身 体組成を推定する場合，本研究で作成した身体密 度推定式を利用することが有用であると考えられ る。

(受付 平成 6 年 3 月 28 日)

\section{考文献}

1) Brožek, J. and A. Keys (1951): The evaluation of leanness-fatness in man: Norms and Interrelationships. Br. J. Nutr., 5, 194-206.

2) Brožek, J., F. Grande, J. T. Anderson and A. Keys 
(1963) : Densitometric analysis of body composition: Revision of some quantitative assumptions. Ann. N. Y. Acad. Sci., 110, 113-140.

3) Bulbulian, R.(1984): The influence of somatotype on anthropometric prediction of body composition in young women. Med. Sci. Sports Exerc., 16, 389-397.

4) Foster, C., M. Pollock, P. Farrell, M. Maksud, J. Anholm and J. Hare (1982) : Training resposes of speed skaters during a competitive season. Res. Quart. Exer. Sports., 53, 243-246.

5) 福永哲夫 (1985): 女子競技選手の皮下脂肪の特徵. 体育の科学, 3, 297-301.

6) 福永哲夫, 金久博昭(1990)：日本人の体肢組成. 初 版, 朝倉書店, 東京, 1-73.

7) Hanson, J. S. (1975) : Changes in body composition and physique of nordic skiers during a competitive season. Med. Sci. Sports Exerc., 7, 213216.

8) Henry, N. W., J. F. Smith, E. D. Mansfield, M. D. Conerly and P. A. Bishop (1986): Validation of body composition models for high school wrestler. Med. Sci. Sports Exerc., 18, 216-224.

9) Katch, F. I. and E. D. Michael, Jr. (1968): Prediction of body density from skinfold and girth measurements of college females. J. Appl. Physiol., 25, 92-94.

10) Keys, A. and J. Brožek (1953) : Body fat in adult man. Physiol. Review., 33, 245-325.

11) 北川 毫(1987)：スポーツに打け栄養と体つくく り. 臨床スポーツ医学, 4, 1331-1337.

12) 北川 薏(1988)：皮下脂肪厚測定. 保健の科学, 30, $342-348$.

13）北川 蔗 (1991)：身体組成とウェイトコントロー ル. 初版, 杏林書院, 東京, 26-160.

14）北川 苇(1993)：身体組成を計る. 体育の科学, 43, 252-256.

15）北川 蒸, 船越 謙, 菅嶋康浩, 松岡弘記(1984)： 皮脂厚からの脂肪量推定の検討. 体力科学, 33, 494 .

16) Lewis, S., W. L. Haskell, H. Klein, J. Halpern and P. D. Wood (1975) : Prediction of body composition in habitually active middle-aged men. J. Appl. Physiol., 39, 221-225.

17) Lohman, T. G., M. L. Pollock, M. H. Slaughter, L.
J. Brandon and R. A. Boileau (1984) : Methodological factors and the prediction of body fat in female athletes. Med. Sci. Sports Exerc., 16, 9296.

18) Lohman, T. G., M. H. Slaughter, R. A. Boileau, J. Bunt and L. Lussier(1984) : Bone mineral measurements and their relation to body density in children, youth and adults. Human Biol., 50, 667 679.

19) Malina, R. M., W. H. Mueller, C. Bouchard, R. F. Shoup and G. Lariviere (1982): Fatness and fat patterning among athletes at the Montreal Olympic Game 1976. Med. Sci. Sports Exerc., 14, 445452.

20）丸山康子，飯塚幸子，吉田敬一(1991)：超音波法に よる日本人青年の皮下脂肪分布の性差. Ann. Physiol. Anthrop., 10, 61-70.

21) Meleski, B. W. and R. M. Malina(1985): Changes in body composition and physique of elite university-level female swimmers during a competitive season. J. Sports Sci., 3, 33-40.

22) Mayhew, J. L., F. C. Piper, J. A. Kossand and D. H. Montaldi (1983) : Prediction of body composition in female athletes. J. Sports Med. and Physical Fitness, 23, 333-340.

23) Nagamine, S. and S. Suzuki (1964) : Anthropometry and body comoposition of Japanese young men and women. Human Biol., 36, 8-15.

24) Parr, R. B., R. Hoover, J. H. Willmore, D. Bachmanand and R. K. Kerlan (1978) : Professional basketball players: Athletic profiles. Phys. Sportsmed., 6, 77-84.

25) Pollock, M. L., E. E. Laughridge, B. Coleman, A. C. Linnerud and A. Jackson (1975) : Prediction of body density in young and middle-aged women. J. Appl. Physiol., 38, 745-748.

26) Pollock, M. L., T. Hickman, Z. Kendrick, A. Jackson, A. C. Linnerud and G. Dawson (1976) : Prediction of body density in young and middleaged men. J. Appl. Physiol., 40, 300-304.

27) Rahn, H., W. O. Fenn and A. B. Otis (1949): Daily variations of vital capacity, residual air, and expiratory reserve including a study of the residual air method. J. Appl. Physiol., 1, 725-736. 
28) Sinning, W. E. (1978): Anthropometric estimation of body density, fat, and lean body weight in women gymnasts. Med. Sci. Sports Exerc., 10, 243-249.

29) Thorland, W. G., G. O. Johnson, G. D. Tharp, T. G. Fagot and R. W. Hammer (1984) : Validity of anthropometric equations for the estimation of body density in adolescent athletes. Med. Sci. Sports Exerc., 16, 77-81.
30) Wilmore, J. H. and A. R. Behnke (1970): An anthropometric estimation of body density and lean body weight in young women. Am. J. Clin. Nutr., 23, 267-274.

31) Wright, G. R., T. Bompa and R. J. Shephard : Physiological evaluation of winter training pro. gramme for oarsmen. J. Sports Med. Physical Fitness, 16, 22-37. 